\title{
SERVICE LIFE EXTENSION OF PARACHUTES WITH USE OF NON-DESCTRUCTIVE AND PARTIALLY DESTRUCTIVE TESTING METHODS OF TEXTILE MATERIALS
}

\author{
Krzysztof Stanisław Szafran ${ }^{1}$ O ORCID 0000-0003-3974-1466 \\ Ireneusz Kramarski ${ }^{2}$ • ORCID 0000-0001-9525-7877 \\ ${ }^{1}$ Łukasiewicz Research Network - Institute of Aviation, Al. Krakowska 110/114, \\ 02-256 Warsaw, Poland \\ ${ }^{2}$ HORNET, ul. Dębowa 72/33, 05-100 Nowy Dwor Mazowiecki, Poland \\ krzysztof.szafran@ilot.lukasiewicz.gov.pl \\ irek@kramarski.com.pl
}

\begin{abstract}
The specificity of personal rescue and reserve parachutes is the fact that they are practically never used for jumping during their service life as they are intended for use only in emergency situations. Therefore, these parachutes throughout the entire period of use are only periodically aired and repacked every 6-12 months. Airing and repacking is necessary even if the parachute is only stored. Rescue and reserve parachutes' components wear unevenly because the canopy with the suspension lines is inside the container and the cover, while the external components of the harness and the container undergo typical operational wear. Therefore, the service life of rescue parachutes can even reach 20 years (this refers to the canopy with the suspension lines alone). During normal exploitation, parachutes are subjected to non-destructive visual and tactile inspection in preparation for packing. When a parachute reaches its maximum service life, extension of its service life can be calculated based on its technical condition. The procedure for extending parachute's service life involves non-destructive tests at a fabric air permeability test stand and partially destructive tests at the strength test stand. In the paper, both methods are described and their advantages and disadvantages are discussed. Also, observations some regarding the packers' work and the desired new properties of raw materials that could be introduced to the parachute industry are presented.
\end{abstract}

Keywords: parachute systems, textile materials, fatigue degradation, service life, aviation safety

Article Category: Research Article 


\section{INTRODUCTION}

The specificity of personal rescue and reserve parachutes is the fact that they are practically never used for jumping during their service life as they are intended for use only in emergency situations. Therefore, these parachutes throughout the entire period of use are only periodically aired and repacked every 6-12 months. Airing and repacking is necessary even if the parachute is only stored [1]. In Poland, S-3 rescue parachutes (for LIM and TS-11 Iskra airplanes) and S-4 (for An-2 and An-28 / M28 aircraft as well as $\mathrm{Mi}-2, \mathrm{Mi}-8, \mathrm{Mi}-14$ and $\mathrm{W}-3$ rotorcrafts) were introduced for serial production at the Aviotex plants. Also, the SP-6 rescue back parachute was designed. The SZ-60, SZ-73 and SZ-82 chest parachutes were produced in the reserve parachute group. At the beginning of the $1990 \mathrm{~s}$, the state-owned Aviotex was partially privatized and stopped production of parachutes. The production of S-3 and S-4 rescue parachutes for the Polish Armed Forces was launched at AIR-POL using their technical documentation of these parachutes. AIR-POL also manufactures its own SK-94 rescue back parachute, which also meets the needs of military customers for rescue parachutes. At the beginning of the year 2000, it turned out that it was necessary to secure the needs of sport jumpers in terms of chest reserve parachutes, because parachutes manufactured by Aviotex began to reach the 12-year service life, but their technical condition was very good and potentially allowed extending the period of use by another 3-4 years.

\section{SPECIFICATION OF USING RESCUE AND RESERVE PARACHUTES}

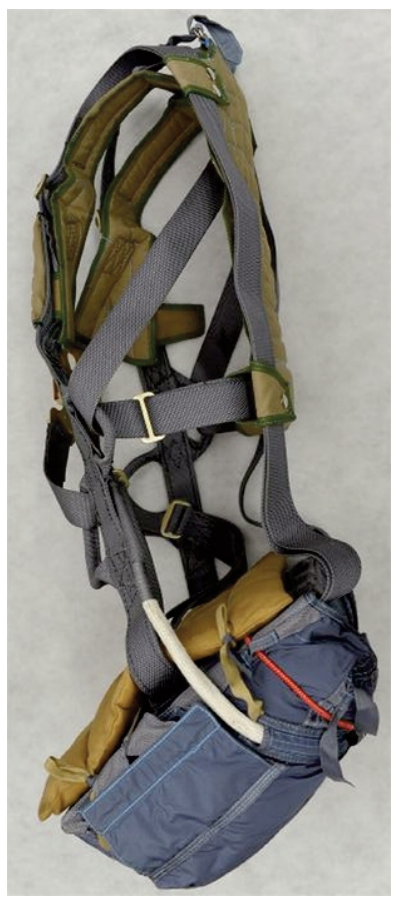

Fig. 1. S-4 seat rescue parachute [7].
Rescue parachutes are required for pilots and cabin crew members when flying by aircraft of the Polish Armed Forces and of the Border Guard [6]. Depending on the difficulty of the mission being carried out and the magnitude of the potential threat, it is required that the cabin crew wear rescue parachutes permanently, and pilots use rescue parachutes mounted in the seats, including ejected seats. When flying in standard peace conditions, rescue parachutes are carried on special racks with easy access in the cabin of the aircraft and in a number ensuring the possibility of rescue for each crew member. Fig. 1 shows a seat rescue parachute with the harness.

Transporting civilians does not require taking rescue parachutes because for economic reasons it is not possible, and for image reasons it is not appropriate to take a large number of rescue parachutes on board an aircraft. In addition, civilians usually do not have any parachute jumping experience and therefore could die using rescue parachutes in the wrong way. In civil aviation, rescue parachutes are required for gliders. However, many pilots and passengers of ultra-light and experimental class aircraft also perform 


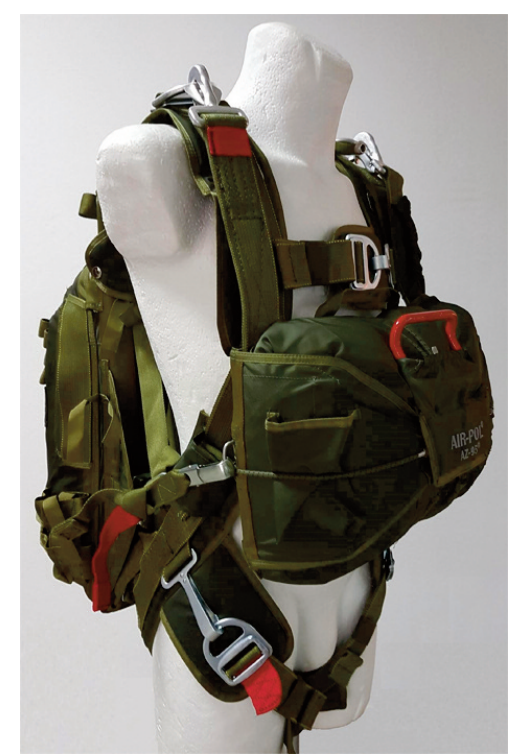

Fig. 2. AZ-95 chest reserve parachute [7]. flights with rescue parachutes, mainly due to a less reliable operation of such an aircraft without a full type certificate.

Reserve parachutes are included in the parachute sets for performing jumps. Jumping is performed on the main canopy, and the reserve canopy is used to save the jumper in an emergency, when the main canopy does not open or opens incompletely. In this case, usually the main canopy is realised (detached) from the jumper's harness and the reserve canopy is opened. Therefore, reserve canopies are also used sporadically only when the main canopy fails. Figure 2 shows a reserve parachute produced in Poland.

Due to the specificity of their use, throughout the entire period of their use, rescue parachutes and reserve parachutes are rarely opened in the air and only periodically aired and repacked every 6-12 months depending on the type of parachute. Airing and repacking is necessary even if the parachute is

stored. During these periodic works, each parachute is subject to the assessment of its current technical condition by a licensed packer (mechanic of service confirmation). In the event of damage or wear of a subassembly or a part the packer performs minor repairs and/or replaces damaged subassemblies with functional ones based on the scope of authorization to operate a parachute of a given type.

\section{RESCUE AND RESERVE PARACHUTES OF POLISH PRODUCTION}

In the second half of the 20th century, the mass production of a Russian origin S-3 seat rescue parachutes for LIM and TS-11 Iskra airplanes and S-4 for An-2 and An-28 / M28 aircraft and for Mi-2, Mi-8, Mi-14, Mi-17 and W-3 rotorcraft was launched at the Aviotex State Technical and Tourist Equipment Plant in Legionowo, Poland. At ZSTiT Aviotex, the SP-6 rescue back parachute was designed independently. The technical condition of the SP-6 parachute after 12 years of operation is shown in Figure 3.
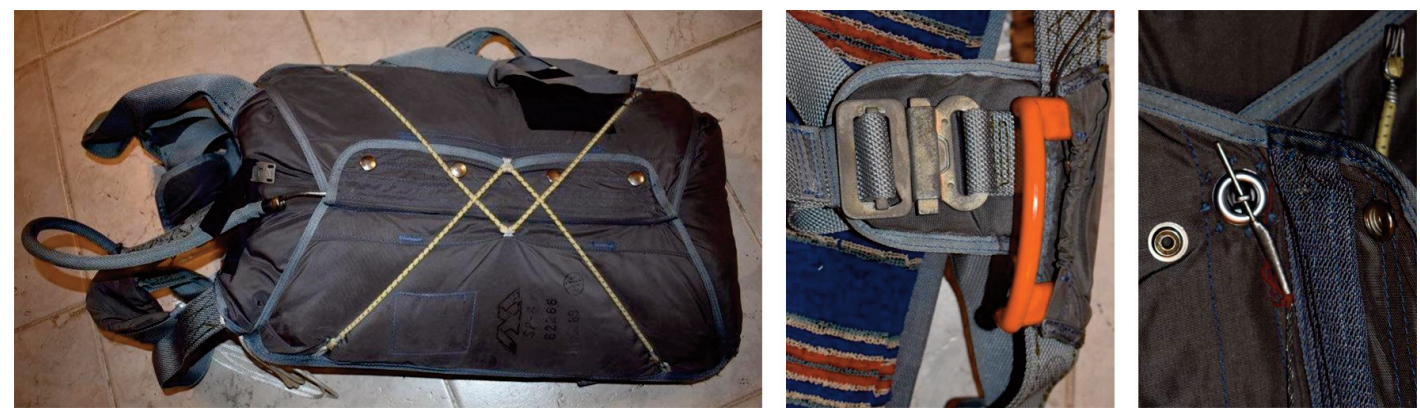

Fig. 3. Parachute SP-6 after 12 years of service life [Kramarski]. 
In the 1990s the production of S-3 and S-4 seat rescue parachutes for the Polish Armed Forces was launched in the parachute factory AIR-POL using their technical documentation of these parachutes. AIR-POL also manufactures its own SK-94 rescue back parachute, which largely secures the needs for rescue parachutes of Polish military users. The above-mentioned parachutes have round or polygonal canopies. AIR-POL also manufactures several types of reserve parachutes, including a round canopy AZ-95 and AZ-95M parachute for the main AD-95 and L-2 Kadet parachutes, respectively. AD-2000 and FENIKS II parachutes are also produced.

\section{EXTENSION OF SERVICE LIFE OF RESCUE AND RESERVE PARACHUTES}

In the parachute industry, the parachute's service life is calculated based on the date of production. Parachutes for performing sport, recreation and landing jumps are used according to the current technical condition and usually not longer than for 12 years. In these parachutes, along with the increasing number of jumps, both the main canopy with the suspension lines and the harness with the cover are subject to wear.

Rescue and reserve parachute components wear unevenly because the canopy with the suspension lines are rarely used while the external components undergo typical operational wear. Therefore, the service life of rescue parachutes can even reach 20 years, but such a long service life refers to the canopy with suspension lines alone because throughout the entire period of use the canopy is protected inside the cover, often also in an additional cover of the opening system [4,5].

It should be noted, however, that the maximum service life is only possible if the parachute is aired and repacked during every a certain period of time (6-12 months) [1], and minor repairs and replacements of damaged components are carried out, which must be documented in the parachute's log book. A parachute without a record has an unknown usage history and cannot be used as a rescue parachute, and is usually scraped.

At the beginning of the year 2000, it turned out it was necessary to secure the needs of sport jumpers in terms of chest reserve parachutes $[7,8]$. The parachutes manufactured by ZSTiT Aviotex began to reach the 12-year time limit for them, but their technical condition was very good and potentially permitted extending the period of use by another 3-4 years. However, in the early 1990s, Aviotex was subject to partial privatization. Along with ownership changes the production of parachutes ceased, and the service of previously produced products was taken care of by the Polish Aeroclub. In response to the existing need to keep hundreds of parachutes in use, at the request of the Polish Aeroclub, the Polish Civil Aviation Authority (ULC) gave permission to carry out examinations of chest reserve parachutes and to extend their service life by 3 years if good technical condition was observed. At that time, the Polish Armed Forces also expressed interest in extending the service life of S-3 and S-4 parachutes. Interested parties turned to the sole parachute factory in Poland at that time, i.e. AIR-POL, which undertook to carry out the necessary work.

The Civil Aviation Authority issued an appropriate operating bulletin, on the basis of which the service life of civil chest reserve parachutes SZ-60, SZ-73 and SZ-82 was to be extended. The extension of S-3 and S-4 seat rescue parachutes was achieved according to the arrangements with the military side [3]. 


\section{NON-DESTRUCTIVE AND PARTIALLY DESTRUCTIVE TESTING OF PARACHUTES}

Personal rescue and reserve parachutes are checked at many stages of the production process. Upon completion, they are additionally checked by a certified packer who, after a positive assessment of the parachute condition, authorizes its use [9]. Civil regulations require a full series of ground and flight tests to be carried out during the parachute certification process. After approval of the test documentation by the aviation authority, no additional flight tests are required. The requirement for in-flight testing may arise when major changes have been made to the parachute design or introduced to the manufacturing process. These cases are dealt by the aviation authorities who decide if additional flight testing may or may not be necessary. In Poland, like in many other countries, military customers require additional in-flight checks to verify whether the parachute opens correctly. In practice, this means that randomly selected parachutes are tested on the ground and in flight. On selected parachutes, flight testing involves dropping weighted mannequins and checking of the parachute's performance at the minimum speed and minimum height as well as at the maximum speed of use for a given type of parachute, as these are the most dangerous conditions during the opening process of the parachute system. In order to assess the static descending performances of a fully open canopy, the jumps are performed by an experimental jumper, who checks the controllability of the canopy and measures the descending speed. After the flight tests, the tested specimens are sent to normal operation, without any time limit.

During normal exploitation, parachutes are subjected to non-destructive visual and tactile inspections. The condition of the canopy and suspension lines raises no objections if there are no any fade in color quality and any changes on the surface of the fabric, reinforcing tapes and suspension lines. The appearance of changes is a sign of loss of strength and/or durability by textiles.

In this case and with any doubts as to the properties of the materials, a non-destructive method of checking the fabric's air permeability of the canopy is used. A change in air permeability indicates damage to the fabric fibers and / or damage to the coating that covers the woven fabric in the manufacturing process [2]. The coating is used to stabilize the fabric's air permeability within the range provided a given type, and it usually also protects the fibers from the effects of solar radiation, mainly UV rays [9]. In some parachute fabrics as well as in reinforcing tapes and suspension lines, an anti-melting coating is also used, whose function is to increase the material's resistance to increased temperature, when during rapid opening, the fabric, reinforcing tapes and suspension lines tear against each other. Evolving heat can damage the fibers of the textile materials and therefore an anti-melting coating is applied that heats up and evaporates first, thus reducing the amount of heat acting on the fibers under the coating. The device for testing the air permeability (air porosity) of the parachute fabric is shown in Figure 4. 


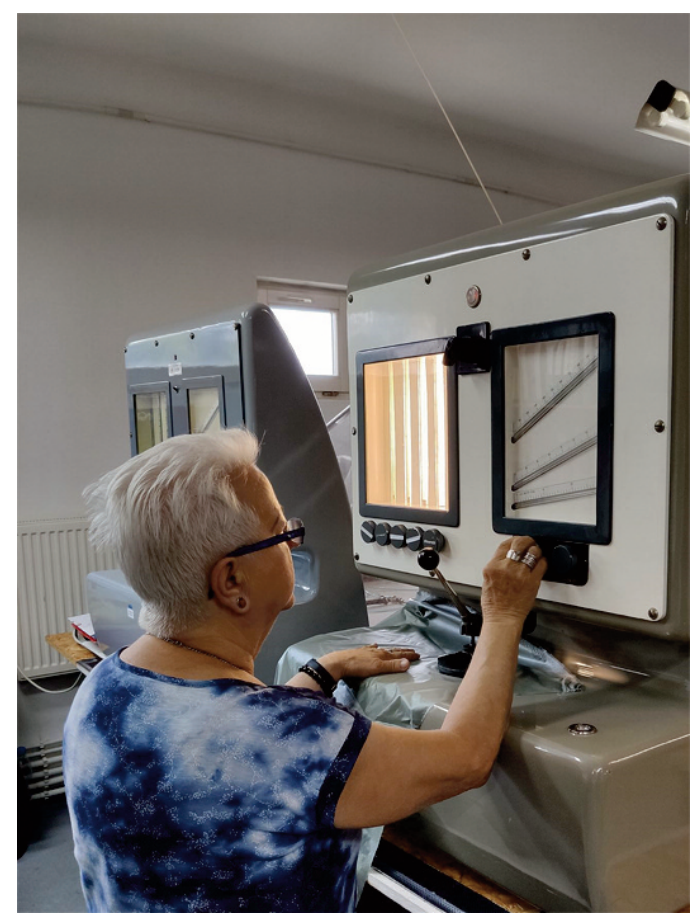

Fig. 4. Testing of the air permeability (air porosity) of the fabric of the parachute canopy [7].

The condition of the external components of the parachute, i.e. the harness, the cover, the release handle, the release cones or grommets of the cover depends on the conditions of use and care of the equipment during its service life. The harness and the cover are exposed to abrasions on the seat and / or surfaces of the aircraft. However, they can also be wet, dirty or faded due to lying in the sun, etc., if the user does not care for the parachute properly. Metal elements are subject to wear due to abrasion of their surface and loss of anti-corrosion ability. Rubber elements age and lose their elasticity.

The main parachute assembly is the canopy with the suspension lines, and the correctness of the parachute's opening system depends primarily on its technical condition. In addition, the canopy with suspension lines is the most expensive element of the parachute system, and therefore methods have been developed for the additional checking of its properties based on performing residual destructive tests. These involve cutting out small samples of the fabric from the sectors of the canopy that raise doubts and testing the actual strength of the fabric. Selected suspension lines and reinforcing tapes are tested in a similar way. Parts of the parachute from which the samples were taken for testing are subject to repair and the strength properties are verified, the parachute may be returned to normal operation. In this way, you can also repair the canopy with locally damaged suspension lines, e.g. by landing in the bushes or on rough ground.

\section{PROCEDURE FOR EXTENDING THE PARACHUTE'S SERVICE LIFE}

In the case of chest reserve parachutes SZ-60, SZ-73 and SZ-82 as well as S-3 and S-4 rescue seat parachutes, each item was subjected to technical inspection, resulting 
in a report listing necessary repairs and replacements of worn components. The elements replaced included new release handles, rubber pullers and cones in the laps closing the covers. If necessary, repairs of the cover, harness and pockets for the release handle were carried out.

The canopies were initially subjected to the non-destructive test at the fabric air permeability test stand. Porosity was tested in randomly selected canopy sectors and at randomly selected points in a given sector. It is known that if the any increase in air permeability of the fabric indicates some damage has occurred even if there are no visible signs of defect. The parachute with the fabric with increased porosity was removed from service.

Then, from each canopy from the worst-looking sector, a fabric sample was cut out for strength tests. A sample of the suspension line was cut out similarly. The machine used for the lines and threads strength testing is shown in Figure 5.

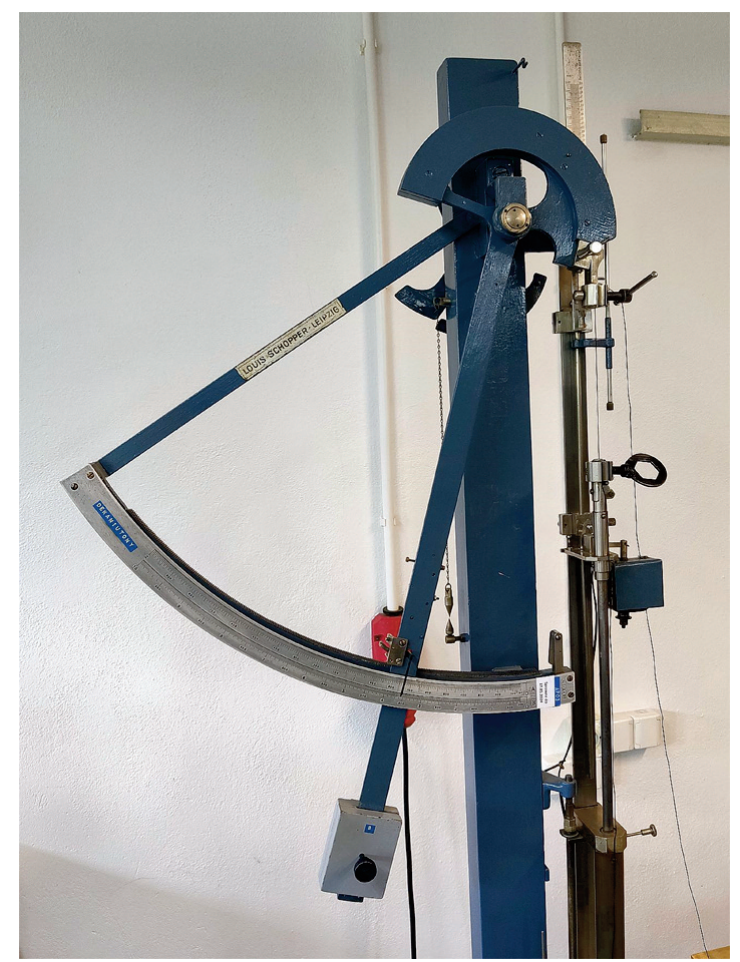

Fig. 5. The parachute lines and threads testing machine [7].

In the case of civilian parachutes, the ULC agreed to extend the period of use if the strength of the fabrics and suspension lines was at least $80 \%$ of the strength of these materials required for new equipment. In the case of positive results of strength tests, the canopy was repaired by sewing patches at the place of cutting out the fabric sample for testing and a new suspension line was installed in place of the line used for strength tests. The tests performed were not destructive for the canopy as only a fragment of one of the twenty several sectors of the canopy was cut out and only one of the twenty several suspension lines. In the case of S-3 and S-4 rescue parachutes, the military accepted the requirements that the strength of fabrics and lines must be at least $100 \%$ of the strength required for new equipment. 


\section{EVALUATION OF WORKS PERFORMED}

During the non-destructive (air permeability) and partially destructive tests, a very good technical condition of the parachute components inside the cover was generally observed (canopy and suspension lines). On the one hand, this confirmed the high quality of the materials used for these components, and on the other it confirmed the belief that professional parachute packers provided excellent technical service throughout the entire existing service life. The cover and harness tapes had signs of many years of use. The metal elements that repeatedly rubbed with each other (zinc coated the steel pins of the release line and the brass cones of the cover in which the pins fall in) required replacement. Similarly, the rubber pullers showed insufficient elasticity and low pulling force due to ageing and were replaced with new ones.

The parachute tests related to the extension of service life offered an opportunity to collect important data on the technical condition of individual components after a long period of use. The use of the non-destructive method for testing the technical state of the canopy fabric by checking its air porosity allowed for refining this test method and introducing it as a test method carried out in the first place for the initial selection of equipment subject to the procedure of extending the service life. Since rescue parachutes are used in emergency situations, it is important to make timely and appropriate decommissioning decisions [12].

\section{OBSERVATIONS AND CONCLUSIONS}

Extending the service life of S-3 and S-4 rescue parachutes and SZ-60, SZ-73 and SZ-80 reserve parachutes allowed the following observations and comments to be formulated:

- Periodic works related to repacks and parachute jumps carried out by certified packers were rated very highly, as no parachute was rejected due to damage to the canopy or suspension lines. This proves high qualifications of professional packers and their high moral level, not allowing permission to use parachutes with questionable properties; textile materials protected by the container and inner covers such as fabrics, tapes and lines showed minimal wear during even 12 years of operation, while maintaining the periodic works schedule in a timely manner;

- External components in the form of containers, covers, harnesses, release handles showed wear depending on the history of use of a given parachute, including primarily the care of the equipment by the direct user;

- The surface condition of steel elements in external components showed traces of abrasion of the zinc corrosion protection layer, which turned out to be less resistant in many years of operation than previously used cadmium plating. However, there is no longer a return to cadmium plating due to the extreme harmfulness of this process to the health of electroplating workers;

- Brass cones are used in the covers closing the containers due to the high corrosion resistance of brass. However, the cones work with the steel pins, which over time causes the holes in the cones to wear out due to the lower hardness of brass compared to steel. 
It should be noted that many of the above problems have already been solved in new materials used in the construction of parachute systems. However, this was also associated with a major mental change, in which the total costs of operating the equipment, i.e. the costs of purchasing it and many years of use, were calculated. With this approach, it turned out that the product was more expensive to buy, because made of raw materials of higher quality and better performance parameters may allow reducing the amount of maintenance work and be operational for a longer period compared to previously purchased products. Some applications of new technologies are shown in [13].

\section{In the Polish parachute technique, at that time the introduction of improvements such as:}

1. Fabrics, reinforcing tapes and suspension lines are made of nylon threads characterized by higher fiber strength and higher temperature resistance compared to similar Polyamide 6 materials produced in Poland earlier; Polyamid 6 has a melting temperature of 215 Centigrades while Polyamid 66 (Nylon) has as high melting temperature as 260 Centigrades and is capable to hold its shape constantly at temperature up to 180 Centigrades [15]. So, there is no need, for example, to cover the fabrics with an additional anti-melting coating, as new raw materials withstand higher temperatures; however, the know-how in the field of anti-melting coatings should be retained, as this makes it possible to use this knowledge, for instance in the field of parachute systems for objects returning to Earth from space; [14].

2. Containers and covers are made of high-strength Cordura class fabrics, which show increased resistance in typical long-term use by pilots;

3. Metal connections (e.g. cone-pin) are changed into line-metal connections, where the line is made of textiles and can even be replaced each time with a new one due to the very low cost of the line and the exclusion of corrosion-related malfunctions;

4. Steel elements with galvanic coatings are replaced with elements made of stainless steel; in new products it is already a standard, and in previously certified products it requires additional tests and arrangements with the aviation supervision;

5. New raw materials allow extending the time between necessary maintenance work, which means lower operating costs for the user; in the case of military users, this reduces the staffing of parachute systems' service personnel and thus reduces overall costs;

6. New raw materials as well as acquired knowledge and experience allow for the construction of parachute systems with higher performance or their use in completely new applications (e.g. parachutes to save entire aircraft).

\section{SUMMARY}

The monitoring of equipment during its operation allows analyzing construction solutions and introducing improvements, with the new observations and conclusions immediately used in new products. However, it should be noted that certified products are used to their maximum possible resources, as their price includes all costs of research and development, implementation and certification as well as current production costs and the producer's profit. 


\section{REFERENCES}

[1] FAA Federal Register amending repack from 120 to 180 days. https://www.pia.com/wp-content/uploads/faa180.pdf

[2] Parachute Handling vs Porosity https://www.hpac.ca/pub/?pid=158

[3] Sekcja Spadochronowa Aeroklubu Warszawskiego, www.skydive.waw.pl

[4] Szafran, K. \& Kramarski, I. (2019). Fatigue Degradation of the Structure of Parachute Systems. Fatigue of Aircraft Structures, 2018(10), 93-103. https://doi.org/10.2478/fas-2018-0009.

[5] Szafran, K. \& Kramarski, I. (2020). Fatigue Degradation of the Ram-Air Parachute Canopy Structure. Fatigue of Aircraft Structures, 2019(11) 103-112. https://doi.org/10.2478/fas-2019-0010.

[6] Szafran, K. (2018). Safety in aviation: critical situations in the aspect of the theory of subjective analysis (In Polish: Bezpieczeństwo w lotnictwie - sytuacje krytyczne w aspekcie teorii analizy subiektywnej). Autobusy-Technika, Eksploatacja, Systemy Transportowe, 19(12), 242-245. https://doi.org/10.24136/atest.2018.391.

[7] AIR-POL Sp.z o. o., www.air-pol.com.pl

[8] U.S. Department of Transportation. (2005). Parachute Rigger Handbook, Federal Aviation Administration, Flight Standards Service.

[9] Moezzi, M., Ghane, M. \& Semnani, D. (2015). Predicting the Tensile Properties of UV Degraded Nylon66/Polyester Woven Fabric Using Regression and Artificial Neural Network Models, Journal of Engineered Fibers and Fabrics, 10(1), 1-11. https://doi.org/10.1177/155892501501000101.

[10] Potvin J. (2009). Updating and Upgrading the World's Database on the Opening Shock Factor $\mathrm{C}_{\mathrm{k}}$. 20th AIAA Aerodynamic Decelerator Systems Technology Conference and Seminar, Seattle USA, AIAA-2009-2905. https://doi.org/10.2514/6.2009-2905.

[11] SIGMA Tandem System Owner's Manual. https://uptvector.com/wp-content/uploads/2018/08/Manual_Sigma_MAN-013.pdf

[12] Szafran, K., Kończak, J. \& Mieteń, M. (2017). Impact of the decision on transport systems' reliability in emergency situations. Journal of Science of the Military Academy of Land Forces, 186(4), 216-230. https://doi.org/10.5604/01.3001.0010.7230.

[13] Szafran, K. \& Kramarski, I. (2015). Safety of Navigation on the Approaches to the Ports of the Republic of Poland on the Basis of the Radar System on the Aerostat Platform. Trans Nav the International Journal on Marine Navigation and Safety of Sea Transportation, 9(1), 131-136. https://doi.org/10.12716/1001.09.01.16.

[14] Szafran, K., Pągowski, Z.T. \& Kramarski, I. (2015). Simulation studies of modular construction elements for hovercraft platform (In Polish: Badania symulacyjne elementów konstrukcyjnych modułowego napędu platformy badawczej na poduszce powietrznej). TTS Technika Transportu Szynowego, 22(12), 1464-1468. ISSN 1232-3829.

[15] ANID Polymers, www.anid.ru. 